\title{
Permian palynoevents in the circum-Arctic region
}

\author{
Gunn Mangerud ${ }^{1^{*}}$, Niall W. Paterson ${ }^{2}$ and Jonathan Bujak ${ }^{3}$ \\ 1. Department of Earth Science, University of Bergen, Allégaten 41 N-5007, Bergen, Norway \\ 2. CASP, West Building Madingley Rise, Cambridge CB3 0UD, UK \\ 3. Bujak Research (International), 114 Abbotsford Road, Blackpool, Lancashire FY3 9RY, UK \\ ${ }^{*}$ Corresponding author: <gunn.mangerud@uib.no>
}

Date received: 25 February 2020 gate accepted: 29 May 2020

\begin{abstract}
Permian palynofloras are recorded around the present-day Arctic and are typically dominated by taeniate and non-taeniate pollen, with intervals of spore domination. The assemblages show close similarities around the Arctic. Based on the published record, we present a compilation of 23 last occurrences (LOs), first occurrences (FOs), and some abundance events. These are anticipated to have regional correlation potential. In general, the Permian palynofloras of the Arctic have not been extensively studied, and the resolution is low due to a general lack of independent age control.
\end{abstract}

\section{RÉSUMÉ}

On observe à l'intérieur de la région arctique des palynoflores permiennes parmi lesquelles prédomine du pollen taeniforme et non taeniforme, avec des intervalles de domination de spores. Les assemblages présentent des similarités étroites à l'intérieur de l'Arctique. Nous basant sur la documentation publiée, nous présentons une compilation des 23 dernières occurrences (DO), des premières occurrences $(\mathrm{PO})$ et de certains phénomènes d’abondance. Nous anticipons que ces phénomènes pourraient être corrélés à l'échelle régionale. De façon générale, les palynoflores permiennes de l'Arctique n’ont pas été considérablement étudiées et la résolution est faible en raison de l'absence générale de critères de datation indépendants.

[Traduit par la redaction]

\section{INTRODUCTION}

This article is a contribution to the Circum-Arctic Palynological Events (CAPE) project, providing a scheme of selected events for the Permian Period. The Permian Period extended from 298.89 to $251.90 \mathrm{Ma}$ according to Gradstein et al. (in press). The Permian is divided into three epochs, Cisuralian, Guadalupian (with a base at 272.3 Ma) and Lopingian (with a base at $259.8 \mathrm{Ma}$ ). A major part of the palynological work from the Permian successions in the Arctic was carried out using the chronostratigraphic scale of Harland et al. (1982). Since stratigraphic standards using Global Stratigraphic Sections and Points was not applied until the late 1990s, correlation and comparison with the earlier palynological charts is difficult; this problem has been com-pounded for the Arctic because a variety of Permian region-al stages have been applied there. This is particularly true around the lower/upper Permian boundary (now Cisuralian/Guadalupian boundary) where, for example, the Roadian stage has been correlated to either the upper Kungurian or to the Ufimian (for example Utting et al. 1997), and the Wordian has been correlated to the Kazanian (see for example Utting and Piasecki 1995). Utting (1989, p. 234) did not use the Kungurian stage. Utting (1994, p. 9) correlated the Roadian to the "Ufimian (?)" and the Wordian to the "Kazanian (?)" (Fig. 1). See Lucas and Shen (2016) for further discussion on Permian chronostratigraphy.

Palynomorphs are the most common, and often the only, fossil group recorded from the Permian, particularly the upper Permian. Palynology is therefore a critical tool for dating and refining stratigraphic correlations of Permian rocks (Stephenson 2016). However, different taxonomic approaches and stratigraphic methods have made comparisons difficult between regions. Especially problematic in the Arctic is the limited communication between Russian and western palynologists; the development especially of a shared taxonomy would likely lead to greatly improved correlations.

Permian palynomorphs are primarily pollen and spores (miospores), although acritarchs, algae and foraminiferal linings also occur. For the Cisuralian, fusulinids and conodonts provide independent age determinations for some of the published palynostratigraphic zones. None of the Permian 


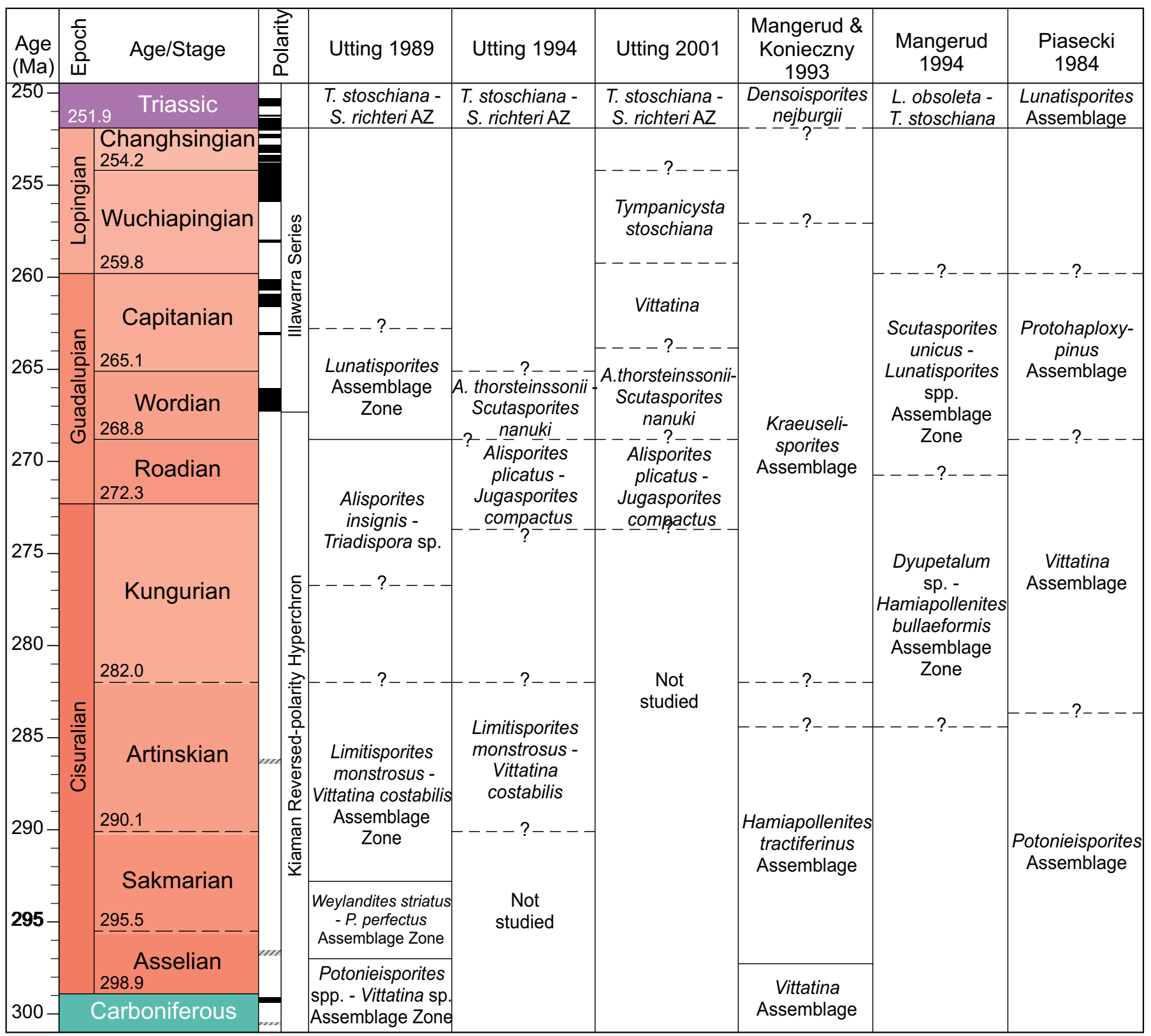

Figure 1. Correlation of published Permian palynological schemes for the Arctic. Abbreviations: $A .=$ Ahrensisporites, $\mathrm{AZ}=$ Assemblage Zone, L. = Lundbladispora, $P .=$ Protohaploxypinus, $S .=$ Striatoabieites, $T .=$ Tympanicysta . Note that Tympanicysta stoschiana (top row indicating basal Triassic zonation) is now considered a taxonomic junior synonym of Reduviasporonites chalastus.

GSSP definitions lists any palynological events, so in general the tie to the chronostratigraphic scale is challenging.

The hotter and dryer climate of the Cisuralian created one of the most marked differentiations into regional floras in the fossil record (Chaloner and Meyen 1973). Consequently, a strong floristic provincialism, with changes to cooler temperate floras in northern areas, characterizes the Permian. Development and evolution of new plants adapted to Permian climates occurred and, by the end of the Paleozoic, seed ferns and early conifers had replaced the swamp-loving lycopods so characteristic of the Carboniferous. These changes are also reflected in the palynofloras (Utting and
Piasecki 1995). The temperate Angaran Province covered Siberia, the Norwegian Arctic and northernmost parts of Greenland and Canada, whereas the East Greenland flora had a mix of Angaran and Euramerican elements.

The present Permian compilation will be added to others from the CAPE Special Issue of Atlantic Geology, which will contribute ultimately (when all articles in the issue are complete) to the "CAPE datapack" in Time Scale Creator (TSC; https://timescalecreator.org/index/index.php) and thus can be used with other data in TSC make plots such as that shown in Fig. 2. Figure 2 includes the age calibration in millions of years (Ma) according to the 2020 version of TSC. 
The events compiled herein include last occurrences (LOs), first occurrences (FOs), and some abundance events. Their relationship to other fossil zonal schemes is shown Fig. 1. Where possible, each event is correlated with the base of a chronostratigraphic unit, for example an ammonoid zone or a formal stage. If the event is not equivalent to the base of such a unit, then an estimation is given as a percentage above the base of the chronostratigraphic unit relative to the entire unit. Details of how a biostratigraphic datapack is constructed in TSC from such information are given in Bringué et al. (in press).

\section{PALYNOSTRATIGRAPHY}

The events compiled herein include last occurrences (LOs), first occurrences (FOs), and some abundance events. Our approach in selecting events has been to use those with multiple reports from the few existing Permian Arctic zonations, especially those calibrated by non-palynological events. However, there are few such cases for the Permian, and many of the events necessarily rely heavily on Utting (1994), who provided the most extensive systematic work on Arctic Permian miospores. The few cases of independent age control are mainly from sparse occurrences of brachiopods, conodonts, fusulinids and ammonoids. It is important to note that many of these cases are not precisely linked to the sampling depths of the palynomorphs. In addition, several hiatuses occur in the successions and almost no palynological data for the Wuchiapingian exist; this is also true, to a lesser extent, for the Changhsingian. Therefore, taxa may have longer ranges than have been documented. Consequently, some of the designated ages probably do not coincide with the true FOs or LOs, but rather with, for example, formation boundaries.

Utting (1994) listed many events as stratigraphically sig-nificant, involving many new taxa; the fact that few of these taxa are reported from elsewhere is a challenge. The problem arises because comparatively few studies of the Permian Arctic have been published subsequent to Utting's work, and also because the many inconsistencies in Permian miospore systematics. As a result, most events are confined to stage boundaries, and uncertainties are major.

In the Sverdrup Basin (Canadian Arctic Islands; Fig. 3), palynostratigraphic works include those by Utting (1985, 1989, 1994, 2001). The article by Barss (1967), which described material from the Sabine Bay Formation, was the only paper published on the Permian of the region prior to 1985. Utting (1985) provided the first detailed stratigraphic study of Permian and lowermost Triassic strata from Melville Island, and represents a pioneering work on the Permian palynology of the Arctic. Utting's samples included those from the uppermost Canyon Fiord Formation, the Belcher Channel Formation, the Sabine Bay Formation, the Assistance Formation, "Unit A" (called "Unnamed" in Utting 1989), the Trold Fiord Formation, and the lower part of the Bjorne Formation. Most identifications were made only to generic level, and no range charts or plates were included. Utting (1985) highlighted the need for taxonomic studies. Independent age control was sparse, but rare brachiopods, bryozoan and fusulinids in the Belcher Channel Formation indicate an early Permian age.

Utting (1989) presented the first palynomorph zonation covering the Carboniferous, Permian and lowest Triassic of the Sverdrup Basin. To date, this is the only palynomorph zonation encompassing the entire Permian System. The study was based on outcrops from across the Sverdrup Basin, in addition to subsurface outcrops from seven wells on Melville Island. The paper provided neither range charts nor plates; however, the zones were described and linked to other fossil groups. All the Permian zones were recorded from both outcrop and subsurface sections. From oldest to youngest, the zones are: the Potonieisporites spp. - Vittatina Assemblage Zone, with conodonts indicating a Gzhelian to Asselian age, the Weylandites striatus - Protohaploxypinus perfectus Assemblage Zone, dated as late Asselian to early Sakmarian by fusulinids, and completely dominated by polyplicate and striate bisaccate pollen, the overlying Limitisporites monstruosus - Vittatina costabilis Assemblage Zone, which had a similar taxonomic composition to the underlying zone, with conodonts indicating a late Artinskian age; and the Alisporites insignis - Triadispora sp. Assemblage Zone, which in contrast had an extremely varied assemblage of trilete spores. Utting indicated the age as late Artinskian to Roadian. No strata of Capitanian or younger Permian were identified.

Utting (1994) studied nine outcrop sections from Melville, Devon and Ellesmere islands, all representing basin-margin or basin-centre successions. He established three Permian palynomorph zones: the Limitisporites monstruosus - Vittatina costabilis Assemblage Zone of Artinskian age; the Alisporites plicatus - Jugasporites compactus Concurrent Range Zone (previously called Alisporites insignis - Triadispora sp. Zone) of Kungurian to Roadian age; and the Ahrensisporites thorsteinssonii - Scutasporites nanuki Concurrent Range Zone (previously called Taeniaesporites Assemblage Zone) of Wordian age. The Permian part of the study covered the Trold Fiord and Van Hauen formations and their basin margin equivalents. Utting (1994) also provided a comparison to assemblages in other geographic areas, but most importantly he provided the first systematic palynological study published from the Arctic (outside Russia), including range charts (albeit with no quantitative data) and plates. Utting (1994) described 39 new species and two new genera and proposed seven new combinations.

Utting (2001) compared Permian palynomorph assemblages between Arctic areas and discussed the challenges in making correlations. He highlighted the fact that there are major differences in taxonomic composition between assemblages from the Russian stratotype areas (of the Ufimian and Kazanian) and those of the Canadian Arctic, which he relates to floral provincialism.

From the Barents Sea area (Fig. 3), Permian palynological studies are limited to those of Mangerud and Konieczny 


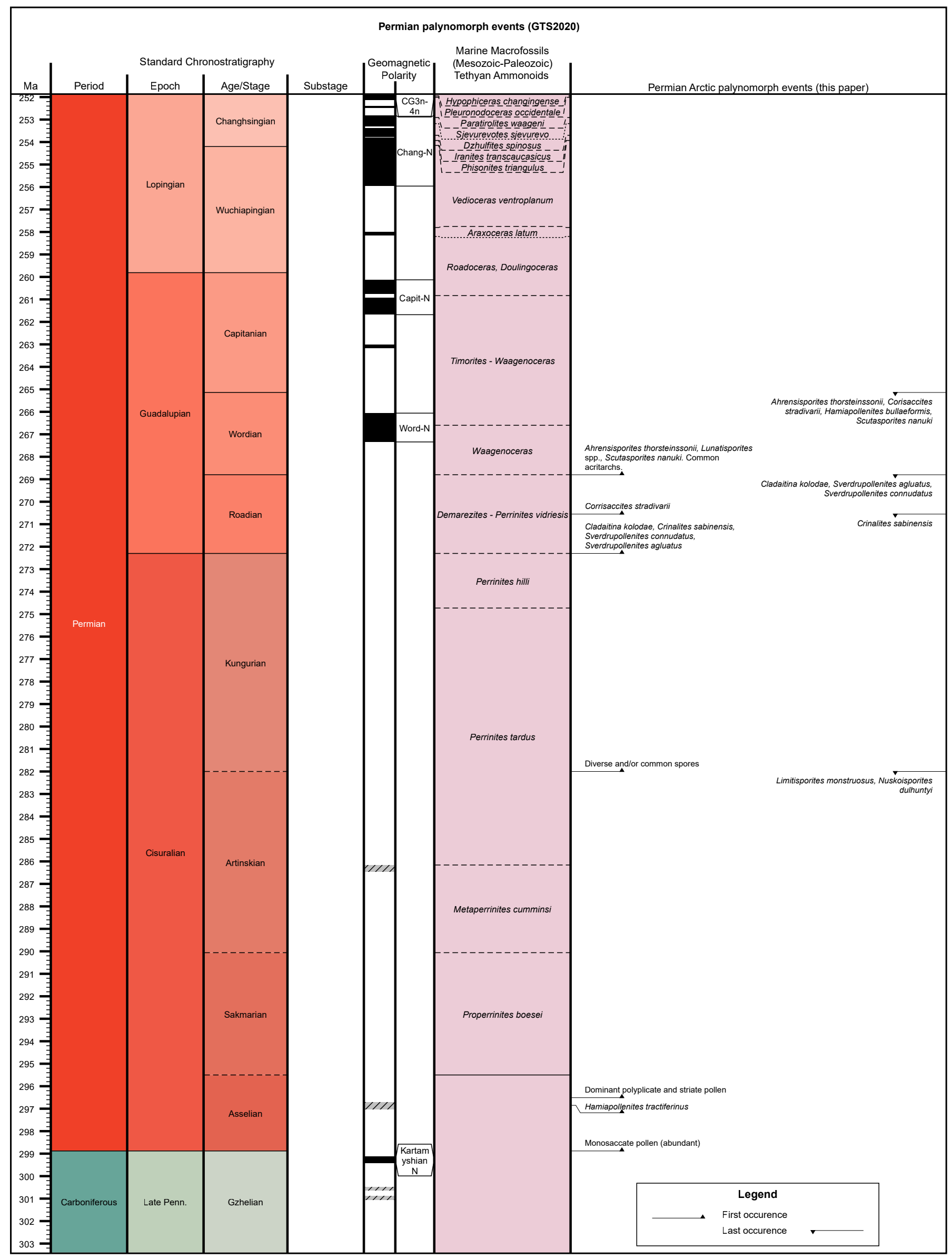

Mangerud et AL. - Permian palynoevents in the circum-Arctic region 
(1991, 1993), Nilsson et al. (1996), Mangerud (1994) and Vigran et al. (2014). In addition, Nakrem et al. (1992) published a review of the Permian biostratigraphy of Svalbard in which they attempted to correlate brachiopod, bryozoan, conodont, fusulinid and palynomorph data. The Cisuralian in this region is carbonate-dominated and palynomorphs are sparse; thus fusulinids provide the best dating tool in this part of the succession.

Mangerud and Konieczny (1991) recognized three assemblages from Nordaustlandet, Svalbard (Fig. 3). The oldest assemblages spanned the uppermost part of the Nordenskioldbreen and lowermost Gipshuken formations with Vittatina, comprising $70 \%$ of the assemblages. The assemblages from the overlying Gipshuken Formation were poorly preserved, whereas assemblages from the Kapp Starostin Formation yielded moderately well-preserved palynomorphs, dominated by marine acritarchs.

Based on 16 sections from Spitsbergen, Mangerud and Konieczny (1993) defined three Permian assemblages, incorporating those described from Nordaustlandet. These were the Vittatina Assemblage and the Hamiapollenites tractiferinus Assemblage from the Cisuralian Nordenskioldbreen and Gipshuken formations, and the Kraeuselisporites Assemblage from the Guadalupian - ?Lopingian Kapp Starostin Formation. Marine acritarchs including Micrhystridium and Veryhachium were present in all samples from the Kapp Starostin Formation.

Subsequent studies in the Barents Sea area by Mangerud (1994) and Nilsson et al. (1996) were based on shallow stratigraphic cores (each a maximum $580 \mathrm{~m}$ long); these represent a unique database for the Norwegian Barents Sea area. All sites were combined with high resolution seismic data, enabling correlation to conventional seismic data (Rise and Sættem 1994). Mangerud (1994) refined the Guadalupian-?Lopingian palynostratigraphy of the Finnmark Platform, suggesting two palynozones: the Dyupetalum sp. - Hamiapollenites bullaeformis Assemblage Zone of ?Kungurian to Ufimian (Roadian/Wordian) age, and the Scutasporites sp. cf. S. unicus - Lunatisporites sp. Concurrent Range Zone of Kazanian (Capitanian) age (Fig. 1). Marine acritarchs including Micrhystridium and Veryhachium are present throughout both zones. Nilsson et al. (1996) described a palynological assemblage from the Tempelfjorden Group in the Svalis Dome, including Scutasporites nanuki, Lueckisporites virkkiae and Lunatisporites spp., which indicate a Kazanian age. Although focusing primarily on the Triassic, Vigran et al. (2014) described two palynozones from the upper Permian: the Uvaesporites imperialis Composite Assemblage Zone of Changhsingian age, and the Reduviasporonites chalastus Composite Assemblage Zone of latest Changhsingian - earliest Induan age.

To date, relatively few palynological studies have treated the Permian of Greenland (Fig. 3). Most of these have fo- cused on the East Greenland Basin, including those by Balme (1980), Piasecki (1984), Looy et al. (2001), Twitchett et al. (2001) and Schneebeli-Hermann et al. (2017). Currently, there is no standard palynological zonation for Permian strata in the region. Balme (1980) focused on the Ravnefjeld and Wordie Creek formations at Kap Stosch on the Hold with Hope peninsula, describing three informal palynozones: the Vittatina Association, the Protohaploxypinus Association and the Taeniaesporites Association. The Vittatina Association was considered to be of Dzulfian age (in the sense of Furnish 1973) based on long-distance correlation, while the overlying Protohaploxypinus and Taeniaesporites associations were assigned to the Griesbachian based on ammonoid and conodont evidence. Piasecki (1984) described four informal zones from the Permian Lower Triassic deposits of Jameson Land and Scoresby Land: the Potonieisporites (early Permian), the Vittatina (latest early - late Permian), Protohaploxypinus (Kazanian - Tatarian) and the Taeniaesporites assemblages (Early Triassic). Looy et al. (2001) and Twitchett et al. (2001) documented the palynofloral succession in an expanded and conformable Permian/Triassic boundary section spanning the Schuchert Dal and Wordie Creek formations in southern Jameson Land. Schneebeli-Hermann et al. (2017) described an assemblage comparable to the both the Vittatina Association of Balme (1980) and the Vittatina Assemblage of Piasecki (1984), from the Ravnefjeld Formation at Kap Stosch. However, based on a reinterpretation of the conodont fauna, the assemblage was redated as Wuchiapingian. Interestingly, Utting (2001) reported finding taxa diagnostic of his Ahrensisporites thorsteinssonii - Scutasporites nanuki Concurrent Range Zone from an unnamed unit in Amdrup Land, eastern North Greenland (Fig 1). In addition, he studied a few samples from the Kim Fjelde Formation in Peary Land, where he recorded assemblages similar to his Alisporites plicatus - Jugasporites compactus Concurrent Range Zone. From the same area, the Midnatfjeld Formation yielded assemblages that could be correlated with the Ahrensisporites thorsteinssonii - Scutasporites nanuki Concurrent Range Zone (Utting 2001).

Permian palynological data from Alaska are extremely sparse. A few Permian taxa were mentioned by Jones and Speers (1976) from the Echooka Formation, and Utting (2001) summarized findings from one core sample from the same formation, revealing assemblages similar to those of the Sverdrup Basin.

Substantial palynological work has been carried out on Permian successions in Russia, but these mostly focus on systematics; they are mostly in Russian (sometimes with short English abstracts). The different taxonomic approach by Russian authors makes comparisons with western data difficult, and resolution will require future collaboration between Russian and non-Russian workers.

Figure 2. (previous page) Chronostratigraphic plot generated using TSC showing stratigraphically significant Permian palynological events. Columns to the left of the "Permian Arctic palynomorph events" column are from TSC: broken lines suggest degrees of uncertainty (dashed $=$ probable and dotted $=$ possible $)$. 


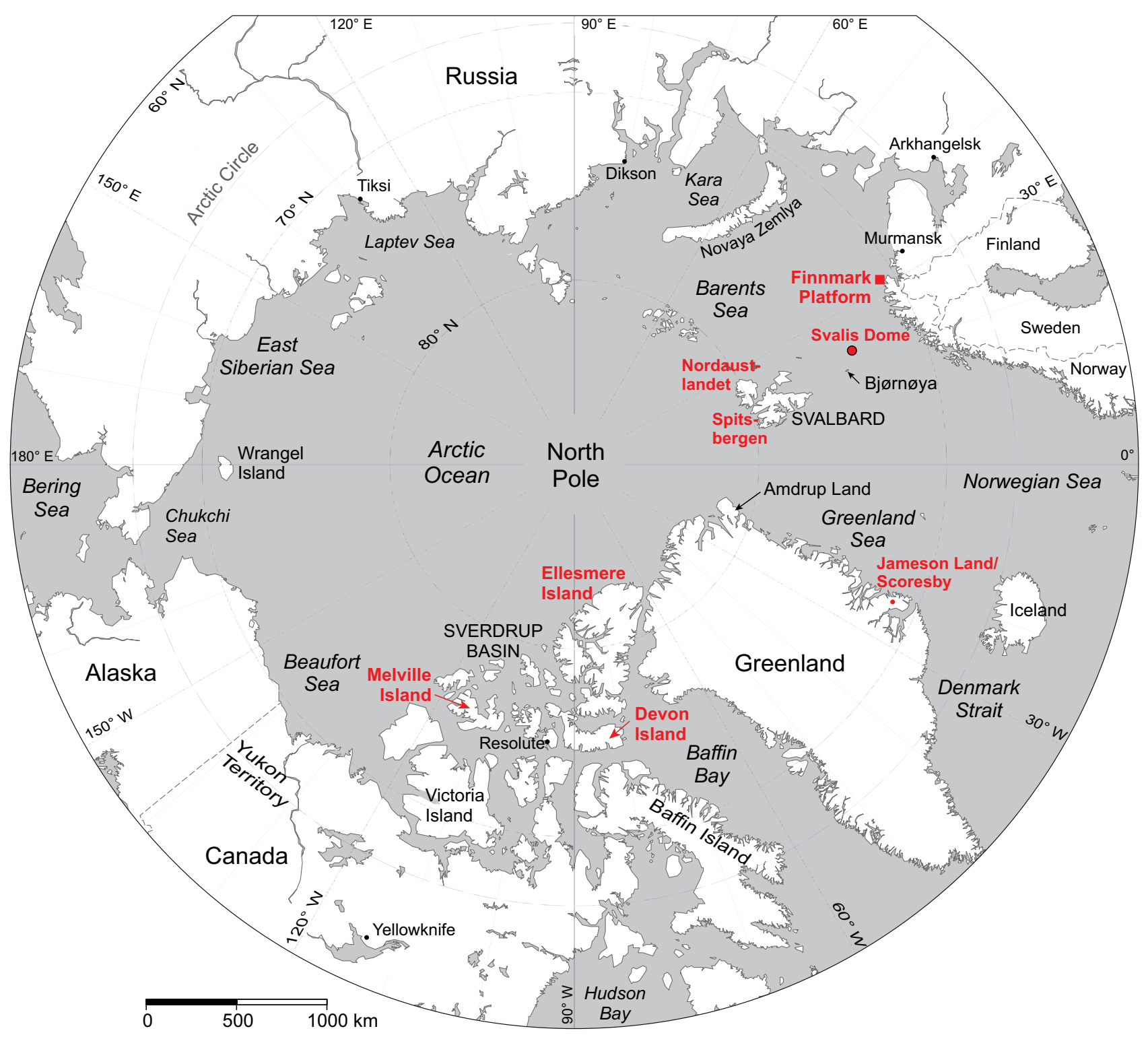

Figure 3. Circumpolar projection map showing the main Permian localities discussed.

\section{PALYNOEVENTS}

\section{FO of consistent Vittatina}

The FO of consistent Vittatina, a common Permian palynomorph, appears to be at the base of the Gzhelian stage (uppermost Carboniferous), where for example Utting (1989) recorded it as common from the middle Canyon Fiord Formation. It is reported from beds with conodont data indicating a Gzhelian to Asselian age. Vittatina is also present from the uppermost Carboniferous in Svalbard (Mangerud and Konieczny 1993), extending up into the basal Triassic. In general, Vittatina is known to occur from the late Carboniferous in the Euramerican floral province (Warrington 1996 and references therein).

The FO of consistent Vittatina spp. is taken here as the base of the Gzhelian stage (late Carboniferous).

\section{FO of abundant monosaccate pollen}

The FO of abundant monosaccate pollen is based on Utting's (1989) records from the uppermost Canyon Fiord Formation. According to Utting (1989), conodonts indicate a Gzhelian to Asselian age for the Canyon Fiord Formation, but the age determination of the FO is uncertain. However, occurrences of monosaccate pollen are generally consistent in the Cisuralian Epoch, and their base seems to be near the Carboniferous/Permian boundary. Consistent monosaccate pollen were also recorded in Svalbard from this part of the succession (Mangerud and Konieczny 1993) and mentioned by Warrington (1996) and references therein as a typical feature for the Asselian in the Euramerican floral province in Russia. Also note that in all these areas, monosaccate pollen seems to be rare above the upper Artinskian, although consistently present. 
The FO of abundant monosaccate pollen is taken as the base of the Asselian.

\section{FO of Hamiapollenites tractiferinus}

The FO of Hamiapollenites tractiferinus is based on reported occurrences, including Utting (1989), who reported it from the Weylandites striatus - Protohaploxypinus perfectus Assemblage Zone in the uppermost Canyon Fiord Formation. According to Utting (1989), various fossils, including fusulinids and non-fusulinid foraminifers in the same formation, indicate a late Asselian to Sakmarian age. We suggest therefore that it has a FO within the late Asselian. Hamiapollenites tractiferinus is also reported from beds with various Asselian fossils (including fusulinids and conodonts) from Svalbard (Mangerud and Konieczny 1993; Nakrem et al. 1992).

The FO of Hamiapollenites tractiferinus is in the late Asselian, taken as $60 \%$ up from the base of the Asselian.

\section{FO of dominant polyplicate and striate pollen}

The FO of dominant polyplicate and striate pollen is based on Utting (1989), who reported dominant polyplicate and striate pollen in the Weylandites striatus - Protohaploxypinus perfectus Assemblage Zone from the uppermost Canyon Fiord Formation. Various fossils, including fusulinid and non-fusulinid foraminifers, indicate a late Asselian to Sakmarian age for this formation. Mangerud and Konieczny (1993) also provided quantitative plots in which polyplicate and striate pollen are clearly dominant in the uppermost part of the Nordenskioldbreen Formation and up through the Gipshuken Formation in Svalbard. The general dominance of saccate pollen in the Cisuralian Epoch is discussed by Warrington (1996).

The FO of dominant polyplicate and striate pollen is in the late Asselian, taken as 70\% up from the base of the Asselian.

\section{LO of Nuskoisporites dulhuntyi}

The LO of Nuskoisporites dulhuntyi is based on occurrences reported from Svalbard (Mangerud and Konieczny 1991, 1993; Nakrem et al. 1992). Its youngest occurrence is at the top of the Gipshuken Formation, which is considered to be of ?Sakmarian to Artinskian age based on the occurrences of brachiopods and foraminifers (Nakrem et al. 1992). From the Sverdrup Basin, Utting (1985) mentioned that Nuskoisporites sp. is present in the Potonieisporites novicus Assemblage Zone from the middle Canyon Fiord Formation, but he did not mention specific species. However, he reported no records of Nuskoisporites above the Potonieisporites spp. Vittatina sp. Assemblage Zone. Since it represents a good index species, we include Nuskoisporites dulhuntyi herein, although its relevance for the Sverdrup Basin is uncertain.

The LO Nuskoisporites dulhuntyi is taken as the base of the Kungurian.

\section{LO of Limitisporites monstruosus}

The LO of Limitisporites monstruosus is based on Utting $(1989,1994)$ who defined his Limitisporites monstruosus - Vittatina costabilis Assemblage Zone from the Great Bear Cape Formation; Limitisporites monstruosus ranges to the top of this formation. According to Utting (1994), ammonoids, brachiopods and conodonts give an Artinskian age for the formation. The base of the Great Bear Cape Formation can be tied to the GSSP section (Henderson et al. 2012 and references therein).

The LO of Limitisporites monstruosus is taken as the base of the Kungurian.

\section{FO of diverse and/or common spores}

The FO of diverse and/or common spores in the Permian of the Arctic areas is based on known occurrences of changes in the palynological assemblage composition reported in the literature, including Utting $(1989,1994)$ in the Sverdrup Basin. From the base of the Alisporites insignis - Triadispora sp. Assemblage Zone (Utting 1989; equivalent to the base of the Alisporites plicatus - Jugasporites compactus Assemblage Zone of Utting 1994), Utting recorded extremely varied assemblages of trilete spores from the Sabine Bay and Assistance formations. According to Utting (1994), the age is Roadian based on ammonoids, and Kungurian to Roadian based on conodonts. Mangerud and Konieczny (1993) reported the same trend from the base of the Kapp Starostin Formation on Svalbard, where bryozoans with a Kungurian affinity were reported (Nakrem et al. 1992). Diverse spore assemblages have also been recorded from correlative successions in exploration wells in Barents Sea (GM, unpublished data), as well as from Russia (e.g. Grigoriev and Utting 1998); so this phenomenon is clearly a circum-Arctic event.

The FO common and diverse spores is taken as the base of the Kungurian.

\section{FO of Crinalites sabinensis}

The FO of Crinalites sabinensis is based on material reported by Utting (1994) from the base of the Sabine Bay Formation; it is of Roadian age based on ammonoids. Utting reported this species as stratigraphically significant, occurring in the lower part of his Alisporites plicatus - Jugasporites compactus Assemblage Zone. The affinity of Crinalites sabinensis is undetermined, but it may represent an algal spore or cyst and be of paleoecological significance. Its stratigraphic significance is also uncertain. However, due to its short reported range in the Sverdrup Basin, we include it here.

The FO of Crinalites sabinensis is taken as the base of the Roadian.

\section{FO of Cladaitina kolodae}

The FO of Cladaitina kolodae is based on material reported 
by Utting (1994) from the base of the Sabine Bay Formation; the event is of Roadian age based on ammonoids. Utting reported Cladaitina kolodae as a stratigraphically significant taxon with a range corresponding to his Alisporites plicatus Jugasporites compactus Assemblage Zone.

The FO of Cladaitina kolodae is taken as the base of the Roadian Stage.

\section{FO of Sverdrupollenites connudatus}

The FO of Sverdrupollenites connudatus is based on material reported by Utting (1994) from the base of the Sabine Bay and Assistance formations; these are of Roadian age based on ammonoids, Utting reported Sverdrupollenites connudatus as a stratigraphically significant taxon with a range corresponding to his Alisporites plicatus - Jugasporites compactus Assemblage Zone.

The FO of Sverdrupollenites connudatus is taken as the base of the Roadian Stage.

\section{FO of Sverdrupollenites agluatus}

The FO of Sverdrupollenites agluatus is based on material reported by Utting (1994) from the base of the Sabine Bay Formation, through the overlying Assistance and lower Van Hauen formations. Utting reported Sverdrupollenites agluatus as a stratigraphically significant taxon with a range corresponding to his Alisporites plicatus - Jugasporites compactus Assemblage Zone. Its FO is of Roadian age based on ammonoids (Utting 1994).

The FO of Sverdrupollenites agluatus is taken as the base of the Roadian.

\section{FO of Corisaccites stradivarii}

The FO of Corisaccites stradivarii is based on material reported by Utting (1994) from the Sabine Bay and Assistance formations, which are dated as Roadian based on ammonoids (Utting 1994). Utting reported Corisaccites stradivarii as a stratigraphically significant taxon with a range base in the middle part of the Alisporites plicatus - Jugasporites compactus Assemblage Zone.

The FO Corisaccites stradivarii is considered to be middle Roadian, taken as $50 \%$ up from the base of the Roadian.

\section{LO of Crinalites sabinensis}

The LO of Crinalites sabinensis is based on material reported by Utting (1994) from the base of the Sabine Bay Formation; the formation is regarded as Roadian based on ammonoids (Utting 1994). Utting reported Crinalites sabinensis as a stratigraphically significant taxon occurring in the lower part of his Alisporites plicatus - Jugasporites compactus Assemblage Zone. Note that Crinalites sabinensis does not range to the top of the Alisporites plicatus - Jugasporites compactus Assemblage Zone, and therefore has an older LO than the other stratigraphically significant taxa for that zone.
Crinalites sabinensis is an algal spore or cyst and may have paleoecological significance. Its stratigraphic significance is uncertain. However, due to its short range in the Sverdrup Basin, we include it here.

The LO of Crinalites sabinensis is in the middle Roadian (taken as 50\% up from the base of the Roadian).

\section{LO of Sverdrupollenites connudatus}

The LO of Sverdrupollenites connudatus is based on material reported by Utting (1994) from the Sabine Bay and Assistance formations, which are of Roadian age based on ammonoids (Utting 1994). He reported Sverdrupollenites connudatus as a stratigraphically significant taxon with a range corresponding to his Alisporites plicatus - Jugasporites compactus Assemblage Zone. The species ranges to the top of the Assistance Formation.

The LO of Sverdrupollenites connudatus is taken as the base of the Wordian.

\section{LO of Sverdrupollenites agluatus}

The LO of Sverdrupollenites agluatus is based on material reported by Utting (1994) from the Sabine Bay and Assistance formations, which are of Roadian age based on ammonoids (Utting 1994). He reported Sverdrupollenites agluatus as a stratigraphically significant taxon with a range corresponding to his Alisporites plicatus - Jugasporites compactus Assemblage Zone. Sverdrupollenites agluatus ranges to the top of the Assistance Formation.

The LO of Sverdrupollenites agluatus is taken as the base of the Wordian.

\section{LO of Cladaitina kolodae}

The LO of Cladaitina kolodae is based on material reported by Utting (1994) from the Sabine Bay and Assistance formations, which are of Roadian age based on ammonoids (Utting 1994). He reported Cladaitina kolodae as a stratigraphically significant taxon with a range corresponding to his Alisporites plicatus - Jugasporites compactus Assemblage Zone.

The LO of Cladaitina kolodae is taken as the base of the Wordian.

\section{FO of Ahrensisporites thorsteinssonii}

The FO of Ahrensisporites thorsteinssonii is based on known occurrences reported by Utting (1994) from the Trold Fiord Formation, which is of Wordian age based on brachiopods, conodonts and ammonoids. He defined his Ahrensisporites thorsteinssonii - Scutasporites nanuki Assemblage Zone in part on the range of this species. Ahrensisporites thorsteinssonii has also been recorded in Wordian sections on Kolguyev Island, Russia (Grigoriev and Utting 1998).

The FO of Ahrensisporites thorsteinssonii is taken as the base of the Wordian. 


\section{FO of Scutasporites nanuki}

The FO of Scutasporites nanuki is based on known occurrences reported in the literature (e.g. Utting 1994). Utting (1994) recorded and described Scutasporites nanuki from the Trold Fiord Formation and described his Ahrensisporites thorsteinssonii - Scutasporites nanuki Assemblage Zone based in part on the range of this species. Brachiopods, conodonts and ammonoids in the Trold Fiord Formation indicate a Wordian age. As Scutasporites nanuki has a similar range in Kolguyev Island, Russia (Grigoriev and Utting 1998) and in the Barents Sea (Mangerud 1994, Nilsson et al. 1996), it seems to have a regional significance. Note that this species is synonymous with Scutasporites sp. cf. S. unicus in Balme (1980) and Mangerud (1994).

The FO of Scutasporites nanuki is taken as the base of the Wordian.

\section{FO of common acritarchs}

The FO of common acritarchs for this marine event are based on Utting $(1989,1994)$ who recorded a relatively high proportion of acritarchs from the middle and upper Trold Fiord Formation, where brachiopods, conodonts and ammonoids indicate a Wordian age. Dominance of acritarchs is recorded more or less from the base of the Kapp Starostin Formation in Svalbard (Mangerud and Konieczny 1993), which probably represents an older event; however, acritarchs show repeated peaks up section, one of which may tie to the one recorded in the Sverdrup Basin. Additionally, in the Barents Sea acritarchs occur commonly below the range of Scutasporites nanuki (Mangerud 1994).

The FO of common acritarchs are therefore regarded as local for the Sverdrup Basin and is taken as the base of the Wordian.

\section{LO of Corisaccites stradivarii}

The LO of Corisaccites stradivarii is based on material reported by Utting (1994) from the Trold Fiord Formation, which is dated as Wordian based on brachiopods, conodonts and ammonoids. Utting reported Corisaccites stradivarii as a stratigraphically significant taxon ranging to the top of the Ahrensisporites thorsteinssonii - Scutasporites nanuki Assemblage Zone.

The LO of Corisaccites stradivarii is taken as the base of the Capitanian.

\section{LO of Scutasporites nanuki}

The LO of Scutasporites nanuki is based on known occurrences reported in the literature (e.g. Utting 1994). Utting (1994) recorded Scutasporites nanuki from the Trold Fiord Formation and based his Ahrensisporites thorssteinsonii Scutasporites nanuki Assemblage Zone partly on the range of this species. Brachiopods, conodonts and ammonoids recorded in the Trold Fiord Formation indicate a Wordian age.
As this species has a similar range in Kolguyev Island, Russia (Grigoriev and Utting 1998), and in the Barents Sea (Mangerud 1994, Nilsson et al. 1996), it seems to have a regional significance. However, the LO is uncertain as the Lopingian seems to be missing there, and so its top could be younger. Note that this species is synonymous with Scutasporites sp. cf. S. unicus in Balme (1980) and Mangerud (1994).

The LO of Scutasporites nanuki is taken as the base of the Capitanian.

\section{LO of Ahrensisporites thorsteinssonii}

The LO of Ahrensisporites thorsteinssonii is based on known occurrences reported in Utting (1994), who defined his Ahrensisporites thorsteinssonii - Scutasporites nanuki Assemblage Zone partly on the range of this species from the Trold Fiord Formation. Brachiopods, conodonts and ammonoids recorded in the Trold Fiord Formation indicate a Wordian age. Ahrensisporites thorsteinssonii has also been recorded in Wordian sections on Kolguyev Island, Russia (Grigoriev and Utting 1998).

The LO of Ahrensisporites thorsteinssonii is taken as the base of the Capitanian.

\section{LO of Hamiapollenites bullaeformis}

The LO of Hamiapollenites bullaeformis is based on known occurrences reported in the literature. According to Utting (2001), it ranges to the top of the Wordian. It is also recorded in the Kazanian stratotype (Russia), ranging up to the lower/upper Kazanian sub-stage boundary (intra-Roadian) (Götz and Silantiev 2015). However, the stratotype area is situated much farther south. The range top of Hamiapollenites bullaeformis seems to be older in the Barents Sea area (e.g. Mangerud 1994), so major uncertainties exist in the range of this taxon.

The LO of Hamiapollenites bullaeformis is taken as the base of the Capitanian.

\section{ACKNOWLEDGEMENTS}

We are grateful to Eva Bjørseth (University of Bergen) and Bill MacMillan (Geological Survey of Canada - Atlantic), who helped draft the figures. We also thank Benjamin Bomfleur and Anette Götz for their constructive reviews; and Manuel Bringué for help with the TSC plot (Fig. 2). This article is a contribution to the TransGEM Event Stratigraphy activity of the Geological Survey of Canada's Geo-Mapping for Energy and Minerals Program.

\section{REFERENCES}

Balme, B.E. 1970. Palynology of Permian and Triassic strata in the Salt Range and Surghar Range, West Pakistan. In Stratigraphic boundary problems: Permian and Triassic 
of West Pakistan. Edited by B. Kummel and C. Teichert. University of Kansas Department of Geology Special Publication no. 4, pp. 304-453.

Balme, B.E. 1980. Palynology of Permian-Triassic boundary beds at Kap Stosch, East Greenland. Meddelelser om Grønland, 200 (6), pp. 1-37.

Barss, M.S. 1967. Carboniferous and Permian spores of Canada. Geological Survey of Canada, Paper 67-11, 94 pp.

Bharadwaj, D.C. 1954. Einige neue Sporengattungen des Saarkarbons. Neues Jahrbuch fur Geologie und Palaontologie, Monatshefte, no. 11, pp. 512-525.

Bringué, M., Fensome, R.A., Poulton, T.P., Galloway, J.M., Bujak, J.P., Golding, M.L., Orchard, M.J., and Williams, G.L., in press. The 2020 Canada datapack for TimeScale Creator: a new tool for Mesozoic-Cenozoic stratigraphy of the Canadian North. Geological Survey of Canada, Bulletin 609.

Chaloner, W.G. and Meyen, S.V. 1973. Carboniferous and Permian Floras of the Northern Continents. In Atlas of palaeogeography. Edited by A. Hallam. Elsevier, Amsterdam, pp. 169-186.

Deflandre, G. 1937. Microfossiles des silex crétacés. Deuxième partie. Flagellés incertae sedis. Hystrichosphaeridés. Sarcodinés. Organismes divers. Annales de Paléontologie, 26, pp.51-103 (also paginated as pp. 3-55), pl.11-18 (also labelled as pl. 8-15).

Deunff, J. 1954. Veryhachium, genre nouveau d'hystrichosphères du Primaire. Compte rendu sommaire des séances de la Société Géologique de France, no.13, pp. 305-306.

Elsik, W.C. 1999. Reduviasporonites Wilson 1962: synonymy of the fungal organism involved in the Late Permian crisis. Palynology, 23, pp. 37-41. https://doi.org/10.1080/01 916122.1999.9989519

Foster, C.B. 1979. Permian plant microfossils of the Blair Athol Coal Measures, Baralaba Coal Measures and Basal Rewan Formation of Queensland. Geological Survey of Queensland Publications, no. 372, pp. 1-244.

Furnish, W.M. 1973. Permian stage names. In The Permian and Triassic systems and their mutual boundary. Edited by A. Logan and L.V. Hills. Canadian Society of Petroleum Geologists Memoir, 2, pp. 522-549.

Götz. A.E. and Silantiev, V.V. 2015. Palynology of the Kazanian stratotype section (Permian, Russia): palaeoenvironmental and palaeoclimatic implications. Palaeobiodiversity and Palaeoenvironments, 95, pp. 149-158. https:// doi.org/10.1007/s12549-014-0175-7

Gradstein, F.M, Ogg, J.G., Schmitz, M.D., Ogg, G.M., Agterberg, F.P., Aretz, M., Becker, T.R., Butcher, A., Ernst, R.E., Esmeray-Senlet, S., Fensome, R.A., Gale, A.S., Gréselle, B., Gibbard, P.L., Goldman, D., Grossman, E.L., Halverson, G.P., Henderson, C.M., Hesselbo, S.P., et al. 2020. The Geologic Time Scale 2020. Elsevier, Amsterdam, 2 volumes, ca. $1300 \mathrm{pp}$.

Grigoriev M. and Utting J. 1998. Sedimentology, palynostratigraphy, palynofacies and thermal maturity of Upper Permian rocks of Kolguyev Island, Barents Sea, Russia. Bulletin of Canadian Petroleum Geology, 46 (1), pp. 1-11.
Harland, W.B., Cox, A.V., Llewellyn, P.G., Pickton, C.A.G., Smith, A.G., and Walters, R. 1982. A geologic time scale. Cambridge University Press, Cambridge, $131 \mathrm{pp}$.

Hart, G.F. 1964. A review of the classification and distribution of the Permian miospore: Disaccate Striatiti. Cinquième Congrés International de Stratigraphie et de Geologie du Carbonifére, Compte Rendu, pp. 1171-1199.

Hart, G.F. 1965. The systematics and distribution of Permian miospores. Witwatersrand University Press, Johannesburg, $253 \mathrm{pp}$.

Henderson, C.M., Davydov, V.I., and Wardlaw, B.R. 2012. The Permian Period. In The geological time scale 2012, Volume 2. Edited by F.M. Gradstein, J.G. Ogg, M.D. Schmitz, and G.M. Ogg, pp. 653 - 680. https://doi. org/10.1016/B978-0-444-59425-9.00024-X

Jansonius, J. 1962. Palynology of Permian and Triassic sediments, Peace River Area, western Canada. Palaeontographica Abteilung B, 110, pp. 35-98.

Jizba, K.M. 1962. Late Paleozoic bisaccate pollen from the United States midcontinent area. Journal of Paleontology, 36 (5), pp. 871-887.

Jones H.P. and Speers R.G. 1976. The Permo-Triassic reservoirs of Prudhoe Bay Field, North Slope, Alaska. In North American oil and gas fields. Edited by J. Braunstein. The American Association of Petroleum Geologists Memoir 24, Tulsa Oklahoma, pp. 23-50.

Klaus, W. 1955. Über die Sporendiagnose des deutschen Zechsteinsalzes und des alpinen Salzgebirges. Zeitschrift der Deutschen Geologischen Gesellschaft, 105, pp. 776788 .

Klaus, W. 1963. Sporen aus dem südalpinen Perm. Jahrbuch der Geologischen Bundesanstalt Wien, 106, pp. 229-363.

Klaus, W. 1964. Zur sporenstratigraphischen Einstufung von gipsführenden Schichten in Bohrungen. Erdöl Zeitung, 4, pp. 119-132.

Leschik, G. 1955. Die Keuperflora von Neuewelt bei Basel. II. Die Iso- und Mikrosporen. Schweizerische Paläontologische Abhandlungen, 72, pp. 5-70, pl. 1-10. (Jansonius and Hills, 1976, imply without explanation that this work was published in 1956.)

Looy, C.V., Twitchett, R.J., Dilcher, D.L., van Konijnenburg-van Cittert, J.H.A., and Visscher, H. 2001. Life in the end-Permian dead zone. Proceedings of the National Academy of Sciences of the U.S.A., 98 (14), pp. 78797883. https://doi.org/10.1073/pnas.131218098

Luber, A.A. and Waltz, I.E. 1941. Atlas of miospores and pollen grains of the Palaeozoic of the U.S.S.R; Transactions of the All-Union Scientific Research Institute of Geology (VSEGEI), 139, pp. 1-107 (in Russian).

Lucas, G.S. and Shen, S. 2016. The Permian chronostratigraphic scale: history, status and prospectus. In The Permian timescale. Edited by S.G. Lucas and S.Z. Zhen. Geological Society, London, Special Publications, no. 450, pp. 21-50. https://doi.org/10.1144/SP450.3

Mangerud, G. 1994. Palynostratigraphy of the Permian and lowermost Triassic succession, Finnmark Platform, Barents Sea. Review of Palaeobotany and Palynology, 82, pp. 
317-349. https://doi.org/10.1016/0034-6667(94)90082-5

Mangerud, G. and Konieczny, R.M. 1991. Palynological investigations of Permian rocks from Nordaustlandet, Svalbard. Polar Research, 9 (2), pp. 155-167. https://doi. org/10.1111/j.1751-8369.1991.tb00611.x

Mangerud, G. and Konieczny, R.M. 1993. Palynology of the Permian succession of Spitsbergen, Svalbard. Polar Research, 12 (1) pp. 65-93. https://doi.org/10.3402/polar. v12i1.6704

Nakrem, H.A., Nilsson, I., and Mangerud, G. 1992. Permian biostratigraphy of Svalbard (Arctic Norway) - a review. International Geology Review, 34 (9), pp. 933-959. https://doi.org/10.1080/00206819209465645

Nilsson, I., Mangerud, G., and Mørk, A. 1996. Permian stratigraphy of the Svalis Dome, south-western Barents Sea. Norsk Geologisk Tidsskrift, 76, pp. 27-146.

Piasecki, S. 1984. Preliminary palynostratigraphy of the Permian - Lower Triassic sediments in Jameson Land and Scoresby Land, East Greenland. Bulletin of the Geological Society of Denmark, 32, pp. 139-144.

Potonié, R. and Klaus, W. 1954. Einige Sporengattungen des alpinen Salzgebirges. Geologisches Jahrbuch, 68, pp. 517-546.

Rise, L. and Sættem, J. 1994. Shallow stratigraphic wireline coring in bedrock offshore Norway. Scientific Drilling, 4, pp. 243-257.

Samoilovich, S.R. 1953. Pollen and spores of Permian deposits of Cherdyn and Aktyubinsk in the Lower Urals. Paleobotanicheskii sbornik: Vsesoiuznyi, nauchno-issledovatel'skii geologo-razvedochnyi institut, Leningrad, Trudy, new series 75, pp.5-57 (in Russian).

Schneebeli-Hermann, E., Hochuli, P.A., and Bucher, H. 2017. Palynofloral associations before and after the Permian-Triassic mass extinction, Kap Stosch, East Greenland. Global and Planetary Change, 155, pp. 178-195. https:// doi.org/10.1016/j.gloplacha.2017.06.009

Stephenson, M.H. 2016. Permian palynostratigraphy: a global review. Geological Society, London, Special Publications, no. 450, pp. 321-347. https://doi. org/10.1144/SP450.2

Twitchett, R.J., Looy, C.V., Morante, R., Visscher, H., and Wignall, P.B. 2001. Rapid and synchronous collapse of marine and terrestrial ecosystems during the end-Permian biotic crisis. Geology, 29 (4), pp. 351-354. https://doi. org/10.1130/0091-7613(2001)029<0351:RASCOM >2.0. $\mathrm{CO} ; 2$

Utting, J. 1985. Preliminary results of palynological studies of the Permian and lowermost Triassic sediments, Sabine Peninsula, Melville Island, Canadian Arctic Archipelago.
In Current Research, Part B, Geological Survey of Canada Paper 85-1B, pp. 231-238. https://doi.org/10.4095/120249

Utting, J. 1989. Preliminary palynological zonation of surface and subsurface sections of Carboniferous, Permian and lowest Triassic rocks, Sverdrup Basin, Canadian Arctic Archipelago. In Current Research, Part G, Geological Survey of Canada, Paper 89-IG, pp. 233-240. https://doi. org/10.4095/127606

Utting, J. 1994. Palynostratigraphy of Permian and Lower Triassic rocks, Sverdrup Basin, Canadian Arctic Archipelago. Geological Survey of Canada, Bulletin 478, pp. 1-107. https://doi.org/10.4095/194811

Utting, J. 2001. Permian and Early Triassic palynomorph assemblages from Canadian Arctic Archipelago, Alaska, Greenland and Arctic Europe. Natura Bresciana, Annuario del Museo Civico di Scienze Naturale di Brescia, Monografia, no. 25, pp. 327-340.

Utting, J. and Piasecki, S. 1995. The Palynology of the Permian of northern continents: a review. In Permian of northern Pangea, volume 1, Paleogeography, paleoclimates and stratigraphy. Edited by P.A. Scholle, T.M. Peryt, and D.S. Ulmer-Scholle. Springer Verlag, Berlin, pp. 236-261. https://doi.org/10.1007/978-3-642-78593-1_15

Utting, J., Esaulova, N.K., Silantiev, V.V., and Makarova, O.V. 1997. Late Permian palynomorph assemblages from Ufimian and Kazanian type sequences in Russia, and comparison with Roadian and Wordian assemblages from the Canadian Arctic. Canadian Journal of Earth Science, 34, p 1-16. https://doi.org/10.1139/e17-001

Varyukhina, L.M. 1970. Some species of spores and pollen from the red-coloured coal bearing deposits of the Permian and Triassic of Pechora Priural'e. In Paleozoic flora and fauna of the northeast European part of the U.S.S.R, Moscow-Leningrad, pp. 39-73.

Vigran, J. O., Mangerud, G., Mørk, A., Worsley D., and Hochuli, P.A. 2014. Palynology and geology of the Triassic succession of Svalbard and the Barents Sea. Geological Survey of Norway Special Publication 14, pp. 1-247.

Warrington, G. 1996. Permian spores and pollen. In Palynology: principles and applications, Volume 2. Edited by J. Jansonius and D.C. McGregor. American Association of Stratigraphic Palynologists Foundation, pp. 607-619.

Wilson, L.R. 1962. Permian plant microfossils from the Flowerpot Formation, Greer Country, Oklahoma. Oklahoma Geological Survey, Circular 49, pp. 1-50.

Editorial responsibility: Robert A. Fensome 
APPENDIX A: TAXON NAMES WITH AUTHORSHIPS

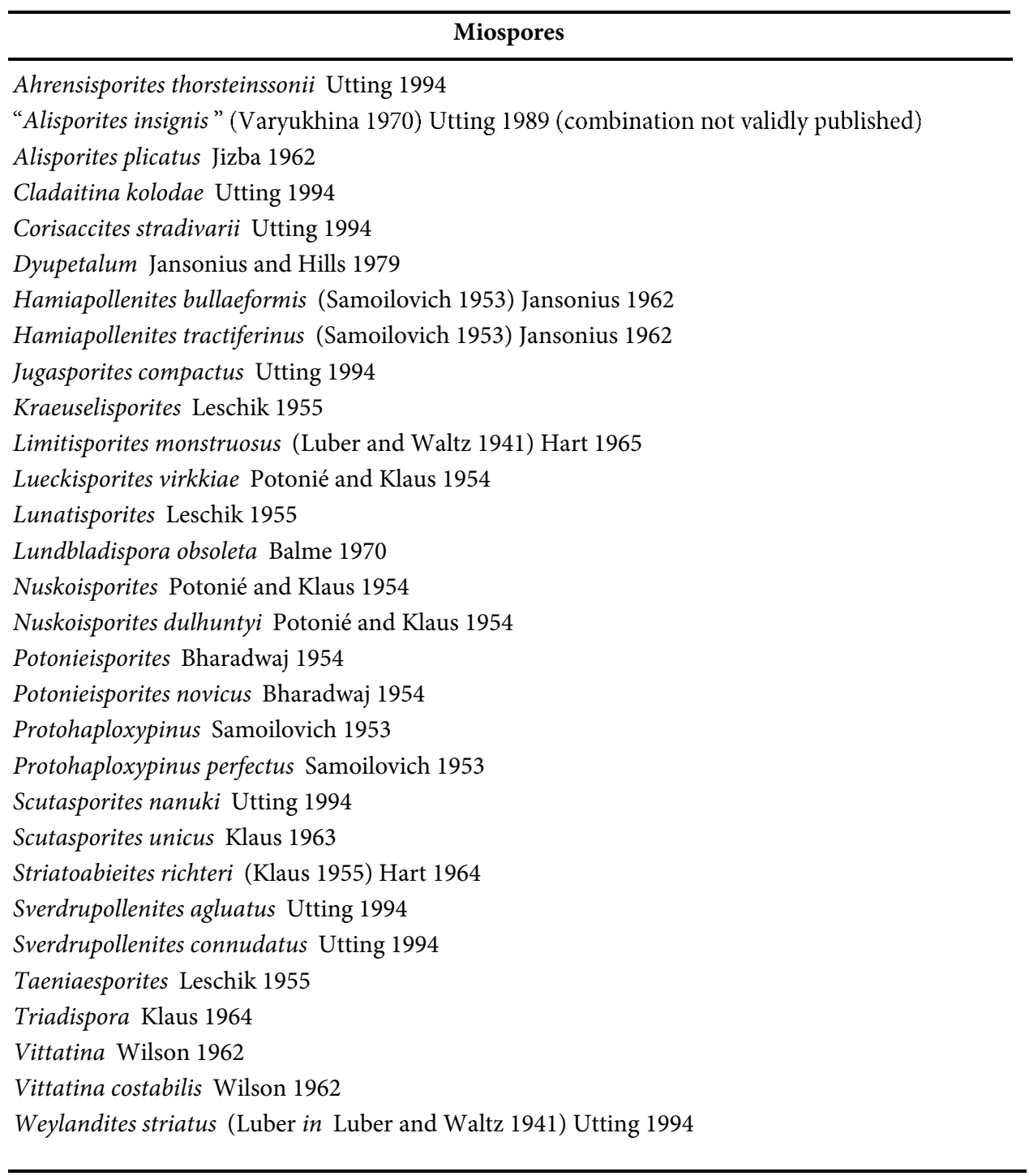

\section{Acritarchs and other groups}

Crinalites sabinensis Utting 1994

Micrhystridium Deflandre 1937

Reduviasporonites chalastus (Foster 1979) Elsik 1999

Tympanicysta stoschiana Balme 1980 (a taxonomic junior synonym of Reduviasporonites chalastus ) Veryhachium Deunff 1954 
APPENDIX B: SPREADSHEET SUMMARIZING PALYNOEVENTS

\begin{tabular}{ll}
\hline \multicolumn{1}{c}{ Event } & \multicolumn{1}{c}{ Summary of TsC link } \\
\hline FO of consistent Vittatina & base of the Gzhelian stage (late Carboniferous) \\
FO of abundant monosaccate pollen & base of the Asselian \\
FO of Hamiapollenites tractiferinus & $70 \%$ up from the base of the Asselian \\
FO of dominant polyplicate and striate pollen & $70 \%$ up from the base of the Asselian \\
LO of Nuskoisporites dulhuntyi & base of the Kungurian \\
LO of Limitisporites monstruosus & base of the Kungurian \\
FO of diverse and/or common spores & base of the Kungurian \\
FO of Crinalites sabinensis & base of the Roadian \\
FO of Cladaitina kolodae & base of the Roadian Stage \\
FO of Sverdrupollenites connudatus & base of the Roadian Stage \\
FO of Sverdrupollenites agluatus & base of the Roadian \\
FO of Corisaccites stradivarii & 50\% up from the base of the Roadian \\
LO of Crinalites sabinensis & $\begin{array}{l}50 \% \text { up from the base of the Roadian } \\
\text { bO of Sverdrupollenites connudatus }\end{array}$ \\
LO of Sverdrupollenites agluatus & base of the Wordian \\
LO of Cladaitina kolodae & base of the Wordian \\
FO of Ahrensisporites thorsteinssonii & base of the Wordian \\
FO of Scutasporites nanuki & base of the Wordian \\
FO of common acritarchs & base of the Wordian \\
LO of Corisaccites stradivarii & base of the Capitanian \\
LO of Scutasporites nanuki & base of the Capitanian \\
LO of Ahrensisporites thorsteinssonii & base of the Capitanian \\
LO of Hamiapollenites bullaeformis & base of the Capitanian \\
\hline &
\end{tabular}

